dr inz.Zygmunt Marciniak, prof.nadzw.

prof. dr hab. inż.Janusz, Mielniczuk,

mgr inz. Wojciech Jakuszko,

mgr inz. Piotr Michalak,

Instytut Pojazdów Szynowych „,TABOR”

\title{
Konstrukcja układów napędu hybrydowego dla wybranych zmodernizowanych lokomotyw spalinowych do ruchu manewrowego i przetokowego
}

\begin{abstract}
Artykut jest poświęcony realizacjom prac zwiqzanych z zastosowaniem uktadów napędu hybrydowego $w$ przewidzianych do modernizacji lokomotyw spalinowych przeznaczonych do prac przetokowych i manewrowych. Zaprezentowano $w$ nim wymagania $i$ wytyczne dla głównych zespotów i uktadów tworzacych napęd hybrydowy. Przedstawiono również spalinowe lokomotywy manewrowe, które zostały wytypowane do zastosowania w nich uktadów napędu hybrydowego oraz zaprezentowano wariantowe rozwiqzania konstrukcyjne możliwe do zabudowy $w$ każdej z wytypowanych lokomotyw. Ponadto przedstawione zostanq parametry głównych zespolów i charakterystyki trakcyjne oraz możliwości lokomotyw w pracy manewrowej z wykorzystaniem zasobników energii. W zakończeniu przedstawiony zostanie zakres dalszych prac konstrukcyjno-wdrożeniowych dla wybranego wariantu oraz możliwości jego realizacji. Artykut zostal przygotowany $w$ ramach projektu rozwojowego wtasnego NR 1000 6210 pt. „Lokomotywa manewrowa z hybrydowym ukladem napędowym z wykorzystaniem wysokowydajnych zasobników energii" finansowanego z budżetu Ministerstwa Nauki i Szkolnictwa Wyższego.
\end{abstract}

\section{WSTĘP}

Ograniczenie szkodliwego oddziaływania pojazdów trakcji spalinowej na środowisko naturalne to przede wszystkim zmniejszenie zużycia oleju napędowego oraz środków smarnych poprzez zastosowanie nowoczesnych silników spalinowych napędu głównego. W ostatnich latach dąży się również do zastosowania innych rodzajów napędów, w tym napędu hybrydowego, w którym zasilanie silników trakcyjnych odbywa się $\mathrm{z}$ wysokowydajnych zasobników energii (ogniwa akumulatorowe, kondensatory) lub z zasobników wspomaganych energią wytworzoną przez zabudowany na lokomotywie zespół prądotwórczy (silnik spalinowy, prądnica prądu przemiennego, prostownik).

Pierwsze pojazdy hybrydowe powstały na bazie samochodów, autobusów, trolejbusów i tramwajów $[1,2]$. Dopiero od kilkunastu lat rozpoczęto prace nad stworzeniem układu hybrydowego napędu z zastosowaniem do lokomotyw przeznaczonych najczęściej do ruchu manewrowego i przetokowego $[2,3,4]$. W Polsce prace wstępne nad stworzeniem układu napędu hybrydowego, w zastosowaniu do modernizowanych spalinowych lokomotyw manewrowych rozpoczęto $\mathrm{w}$ 2010 roku, a szybki ich rozwój nastapił w połowie 2011 roku, kiedy Instytut Pojazdów Szynowych „Tabor" w Poznaniu uzyskał dofinansowanie na wykonanie badań przemysłowych i prac rozwojowych w ra- mach projektu rozwojowego pt. „Lokomotywa manewrowa $\mathrm{z}$ hybrydowym układem napędowym $\mathrm{z}$ wykorzystaniem wysokowydajnych zasobników energii”.

W ostatnich latach $\mathrm{w}$ ramach realizowanego projektu wykonano szeroki i dogłębny przegląd literaturowy układów hybrydowych, przeprowadzono analizę pracy takich układów (w tym badania symulacyjne), przygotowano wstępne wytyczne dla głównych układów i zespołów napędu hybrydowego oraz wykonano koncepcje i założenia lokomotyw, które najbardziej nadawały się do zastosowania tych układów w rzeczywistych konstrukcjach spalinowych lokomotyw manewrowych $[5,6,7,8]$.

W dalszej części artykułu (artykułu) przedstawiony został dalszy ciąg prac związanych z wdrożeniem hybrydowych układów napędowych w jednej (lub kilku) spalinowych lokomotyw manewrowych zmodernizowanych lub przewidzianych do modernizacji.

Zaprezentowano $\mathrm{w}$ nim główne wymagania i wytyczne dla wyszczególnionych zespołów i układów wraz z podaniem ich wstępnych danych technicznych i charakterystyk oraz opracowanymi dokumentacjami konstrukcyjnymi układów napędu hybrydowego. 
Ponadto przygotowano dalszy zakres prac pozwalających na wdrożenie do produkcji i eksploatacji zmodernizowanych lokomotyw spalinowych wyposażonych w układ napędu hybrydowego.

2. WYMAGANIA I WYTYCZNE DLA GLÓWNYCH ZESPOLÓW I UKLADÓW NAPĘDU HYBRYDOWEGO ORAZ KONCEPCJE LOKOMOTYW

Głównymi układami i zespołami wchodzącymi w skład napędu hybrydowego niezależnie od wytypowanej spalinowej lokomotywy manewrowej są [5]:

- silniki spalinowe napędu głównego

- prądnice główne i prostowniki trakcyjne

- przetwornice pomocnicze

- przekształtniki trakcyjne (prąd stały/prąd stały)

- wysokowydajne zasobniki energii

- urządzenia do kontroli i ładowania wysokowydajnych zasobników energii

- silniki trakcyjne oraz przekładnie osiowe

- układy sterowania i diagnostyki napędu.

Wymienione powyżej zespoły i układy powinny spełniać zarówno wymagania normatywne oraz wymagania konstrukcyjne ogólne i szczegółowe. Do najważniejszych należy zaliczyć:

- dla silnika spalinowego to niskie zużycie oleju napędowego i środków smarnych oraz minimalne oddziaływanie na środowisko naturalne (spełnienie wymagań poziomu IIIB dla emisji substancji szkodliwych, takich, jak: CO, HC, NOx oraz cząstek stałych PM)

- dla prądnic głównych to konstrukcja maszyn prądu przemiennego, najczęściej synchronicznych

- dla przekształtników trakcyjnych, przetwornic statycznych to urządzenia (zespoły) mikroprocesorowe zdalne do zasilania obwodów głównych (silniki trakcyjne) i napędów pomocniczych z jednego lub dwóch źródeł zasilania (oddzielnie lub równocześnie)

- dla wysokowydajnych zasobników energii to budowa ogniw o dużej trwałości, małej masie i gabarytach oraz parametrach napięciowo-prądowych zbliżonych do parametrów silników trakcyjnych

- dla układów ładowania zasobników to możliwość ładowania z prostowników prądnic głównych oraz z niezależnego źródła zewnętrznego, najkorzystniejszy czas ładowania, rejestracja i kontrola głównych parametrów takich jak prąd i napięcie ładowania, temperatura, energia użytkowa do zasilania silników trakcyjnych

- dla silników trakcyjnych i przekładni osiowych to pełna modernizacja $\mathrm{z}$ wymianą klasy izolacji oraz zdecydowaną poprawą szczelności układu przemienienia napędu (przekładni, połączeń i osadzeń)
- dla układów sterowania i diagnostyki to budowa mikroprocesorowa $\mathrm{z}$ możliwością nadzorowania i kontroli parametrów pracy najważniejszych zespołów.

Ponadto dla zespołów i układów lokomotyw nie wymagających wymiany i zastosowania nowych maszyn, zespołów i urządzeń, wymagana będzie ich naprawa oraz niezbędna modernizacja.

Szczegółowe wymagania dla wszystkich zespołów i układów wchodzących w skład lokomotyw przewidzianych do wprowadzenia napędów hybrydowych przedstawionych w pracy [12] zależeć będą od typu lokomotywy, ilości zastosowanych zespołów prądotwórczych (silnik spalinowy napędu głównego, prądnice główne, przekształtniki, przetwornice, prostowniki) oraz ilości ogniw tworzących jeden lub kilka modułów wysokowydajnych zasobników energii.

W wyniku przeprowadzonych szczegółowych analiz symulacyjnych modeli hybrydowych układów napędowych [4] zostały przygotowane koncepcje i założenia dla następujących wariantów lokomotyw:

- o układzie osi C (z dwoma silnikami trakcyjnymi) z jednym modułem zasobników i jednym modułem prądotwórczym

- o układzie osi $\mathrm{B}_{0}-\mathrm{B}_{\mathrm{o}}$ (z czterema silnikami trakcyjnymi) z dwoma modułami zasobników i jednym lub dwoma modułami prądotwórczymi

- o układzie osi $\mathrm{C}_{0}-\mathrm{C}_{\mathrm{o}}$ (z sześcioma silnikami trakcyjnymi) $\mathrm{z}$ trzema modułami zasobników i jednym lub trzema modułami prądotwórczymi.

Bazowymi lokomotywami, w których przewidziana będzie zabudowa napędów hybrydowych będą lokomotywy spalinowe do prac przetokowych i manewrowych typu 401Da, 6D (SM42) i TEM2 (SM48) $[6,7,8]$.

Ponadto zdecydowano, że w zależności od realizowanych prac manewrowych i przetokowych lokomotywy hybrydowe umożliwią realizację zadań w trzech różnych wariantach:

- zasilanie silników trakcyjnych bezpośrednio z wysokowydajnych zasobników energii

- zasilanie silników trakcyjnych $\mathrm{z}$ energii zgromadzonej w zasobnikach wspomaganej energią wytworzoną przez prądnicę główną

- zasilanie silników trakcyjnych energią wytworzoną przez prądnice główną tylko dla zjazdów awaryjnych.

Proces zasilania silników trakcyjnych odbywać się będzie automatycznie po odpowiednim ustawieniu nastawnika jazdy i uzależniony będzie od zapotrzebowania na odpowiednią wartość siły pociagowej i realizowanej prędkości [5]. 


\section{KONSTRUKCJA NAPĘDÓW HYBRYDO- WYCH DLA WYBRANYCH SPALINO- WYCH LOKOMOTYW MANEWROWYCH I PRZETOKOWYCH}

Przygotowane koncepcje i założenia hybrydowych układów napędowych oraz wybrane warianty lokomotyw, w których zamierza się je zastosować wyznaczyły kierunki dalszych prac, tj. opracowanie dokumentacji hybrydowego układu napędowego, a następnie jej wykorzystanie $\mathrm{w}$ budowie wybranego wariantu lokomotywy.

Na obecnym etapie kontynuując przygotowane koncepcje $[6,7,8]$ opracowano pięć wariantów układów w zastosowaniu do lokomotyw spalinowych, tj.:

- dla lokomotywy o układzie osi C przeznaczonej zasadniczo do prowadzenia lekkich prac manewrowych i przetokowych - jeden moduł zespołu prądotwórczego i jeden moduł wysokowydajnych zasobników energii

- dla lokomotywy o układzie osi $\mathrm{B}_{0}-\mathrm{B}_{\mathrm{o}}$ przeznaczonej zasadniczo do prac manewrowych o średnim natężeniu oraz do prac przetokowych na liniach głównych - wariant $\mathrm{I} z$ jednym modułem zespołu prądotwórczego i dwoma modułami wysokowydajnych zasobników energii oraz wariant II z dwoma modułami zespołu prądotwórczego i z dwoma modułami wysokowydajnych zasobników energii

- dla lokomotywy o układzie osi $\mathrm{C}_{0}-\mathrm{C}_{\mathrm{o}}$ przeznaczonej do ciężkich prac manewrowych oraz prowadzenia pociagów towarowych na liniach głównych - wariant I z jednym modułem zespołu prądotwórczego i z trzema modułami wysokowydajnych zasobników energii oraz wariant II $z$ trzema modułami zespołów prądotwórczych i z trzema modułami wysokowydajnych zasobników energii.

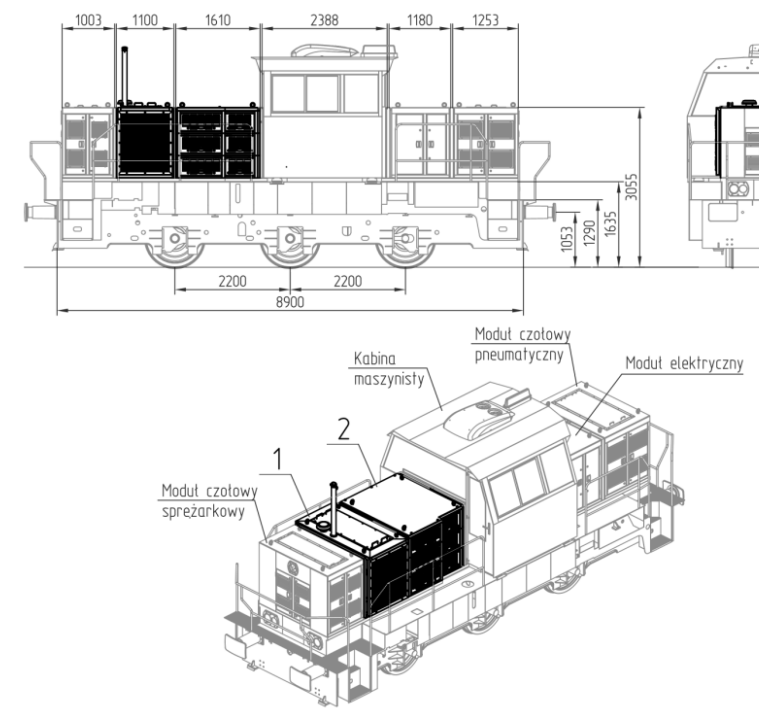

Rys.1 Układ ogólny lokomotywy hybrydowej (z dwoma silnikami trakcyjnymi) $\mathrm{z}$ jednym modułem zespołu prądotwórczego i jednym modułem wysokowydajnych zasobników energii 1 - moduł prądotwórczy 2 - moduł zasobników energii 

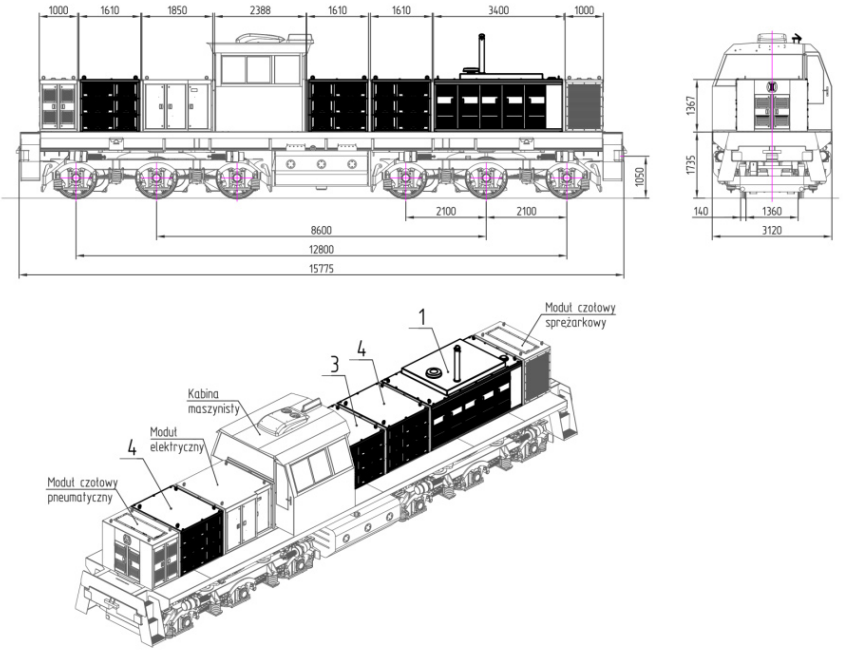

Rys.4 Układ ogólny lokomotywy hybrydowej (z sześcioma silnikami trakcyjnymi) $\mathrm{z}$ jednym modułem zespołu prądotwórczego oraz trzema modułami wysokowydajnych zasobników energii 1 - moduł prądotwórczy 3,4 - moduły zasobników energii
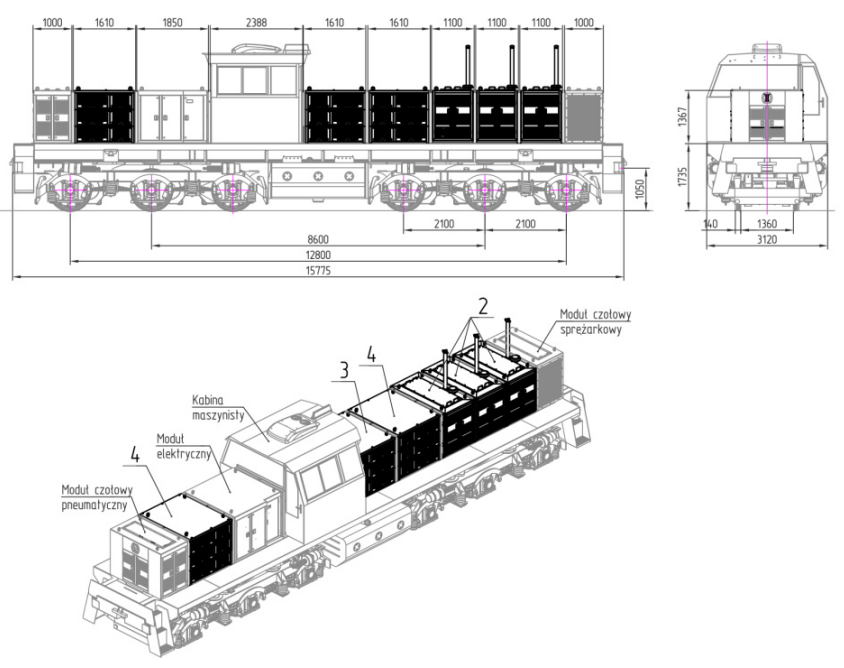

Rys.5 Układ ogólny lokomotywy hybrydowej (z sześcioma silnikami trakcyjnymi) $\mathrm{z}$ trzema modułami zespołu prądotwórczego oraz trzema modułami wysokowydajnych zasobników energii 2 - moduł prądotwórczy 3,4-moduły zasobników energii

Dla wszystkich wariantów lokomotyw pełna dokumentacja hybrydowych układów napędowych obejmowała następujące rysunki i schematy:

- układ ogólny lokomotywy hybrydowej

- zabudowa modułu prądotwórczego wraz z układem ogólnym, obudową, szkieletem, układem drzwi i klap oraz rozmieszczeniem urządzeń i maszyn w module

- zabudowa modułu zasobników energii wraz z układem ogólnym, obudowa, szkieletami segmentów obudowy i dachowego, układu drzwi i klap oraz rozmieszczeniem urządzeń w module

- schematy obwodu prądnicy głównej oraz obwodów zasilania i rozruchu (wraz z wykazami wyposażenia)
- schematy obwodu silników trakcyjnych (wraz z wykazami wyposażenia)

- schematy obwodu rozrządu (w tym schemat połączeń magistrali CAN oraz wykazy wyposażenia)

- schematy sterowania stycznikami silników trakcyjnych (wraz ze schematami wyposażenia)

- schematy zasilania i sterowania napędów pomocniczych (wraz ze schematami wyposażenia).

Przykładowe rysunki zabudowy modułu zespołów prądotwórczych oraz modułu wysokowydajnych zasobników energii przedstawiono na rys. $6 \div 10$.
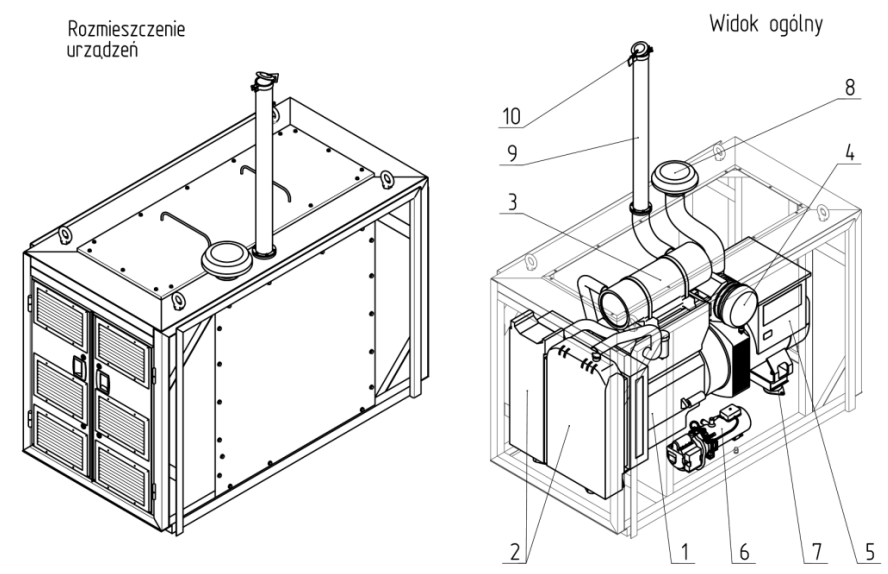

Rys.6 Układ ogólny i rozmieszczenie urządzeń w module zespołu prądotwórczego dla lokomotywy o układzie osi C 1 - silnik spalinowy Caterpillar C 4.4 Acert 2 -zespół chłodnic 3 - system oczyszczania spalin 4 - filtr powietrza 5 - prądnica trakcyjna 6 - podgrzewacz wstępny WEBASTO 7 - podpora elastyczna 8 - osłona wlotu powietrza 9 - komin wylotu spalin 10 - pokrywa komina
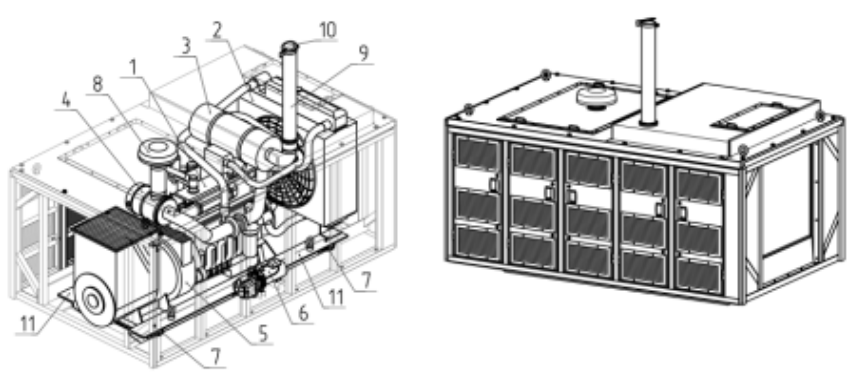

Rys.7 Układ ogólny i rozmieszczenie urządzeń w module zespołu prądotwórczego dla lokomotywy o układzie osi Bo-Bo 1 - silnik spalinowy CATERPILLAR C9.3 ACERT 2 -zespół chłodnic 3 - system oczyszczania spalin 4 - filtr powietrza 5 - prądnica trakcyjna 6 - podgrzewacz wstępny WEBASTO 7 - podpora elastyczna 8 - osłona wlotu powietrza 9 - komin wylotu spalin 10 - pokrywa komina 11 - rama silnika i prądnicy 


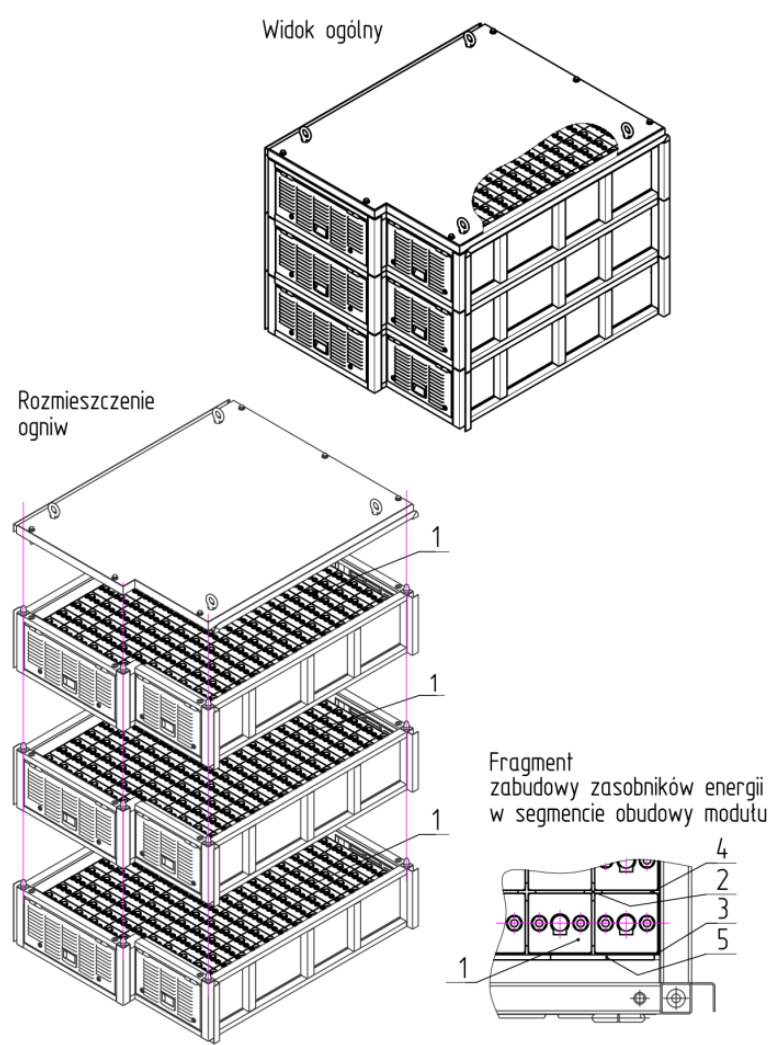

Rys.8 Układ ogólny i rozmieszczenie ogniw w module zasobników energii dla lokomotyw o układach osi $\mathrm{C}, \mathrm{B}_{\mathrm{o}}-\mathrm{B}_{\mathrm{o}}$ i $\mathrm{C}_{\mathrm{o}}-\mathrm{C}_{\mathrm{o}}$ 1 - zespół ogniw typu FNC-A 190 HR 22 - przekładka krzyżowa 3 - przekładka kątowa 4 - przekładka teowa 5 -płyta kompensacyjna

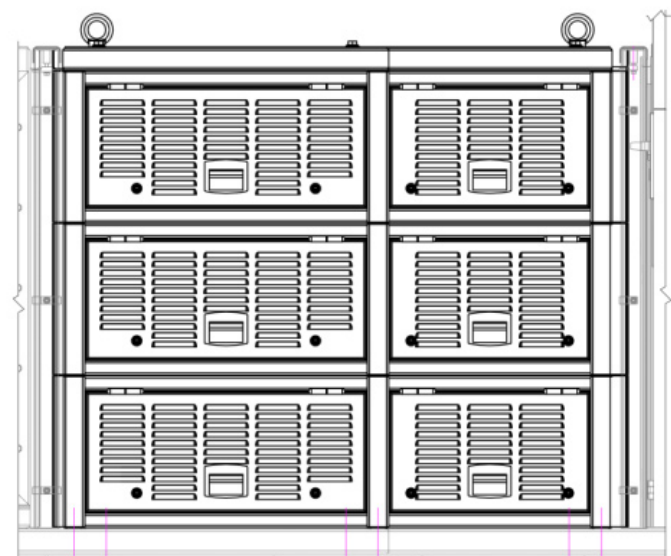

Rys.9 Zabudowa modułu zasobników energii dla lokomotywy o układach

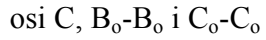

Ponadto na ostojach każdej z lokomotyw przyporządkowane i mocowane są moduły nowoczesnej kabiny sterowniczej $\mathrm{z}$ dwoma stanowiskami, moduł czołowy sprężarkowy (wraz z układami oświetlenia i sygnalizacji), moduł czołowy pneumatyczny z tablicą pneumatyczną i zbiornikami powietrza oraz moduł aparatury i urządzeń elektrycznych.

Moduły te wymagać będą oddzielnego rozpracowania dla wybranego wariantu lokomotywy i wariantu układu napędu hybrydowego przewidzianego do realizacji.

Wszystkie inne zespoły i układy, takie jak układy biegowe i wózki, ostoje, urząadzenia pociagowo-zderzne, odgarniacze, układy stopni i poręczy itp. będą $\mathrm{w}$ miarę potrzeby modernizowane lub poddane naprawom głównym.

Szczegółowa dokumentacja konstrukcyjna dla poszczególnych wariantów lokomotyw wyposażonych w hybrydowe układy napędowe przedstawiono w pracach $[9,10,11]$.

\section{PARAMETRY GLÓWNYCH ZESPOLÓW ORAZ CHARAKTERYSTYKI I MOŻLIWO- ŚCI TRAKCYJNE SPALINOWYCH LOKO- MOTYW HYBRYDOWYCH}

Dla każdego z opracowanych wariantów lokomotyw zostały określone parametry głównych zespołów, które są już produkowane i charakteryzują się wysokim poziomem technicznym oraz wyznaczane parametry zespołów, których produkcję należałoby uruchomić w czasie budowy i modernizacji lokomotyw bazowych [13].

I tak:

1) dla lokomotywy o układzie osi C (z jednym modułem zespołu prądotwórczego i jednym zespołem wysokowydajnych zasobników energii) wytypowano:

a) silnik spalinowy typu Caterpillar C4.4 Acert o mocy $92,5 \mathrm{~kW}$, obrotach $22001 / \mathrm{min}$, momencie obrotowym $530 \mathrm{Nm}$, masie $700 \mathrm{~kg}$ pracujący cyklicznie z pełną mocą max do $80 \%$ całkowitego czasu pracy

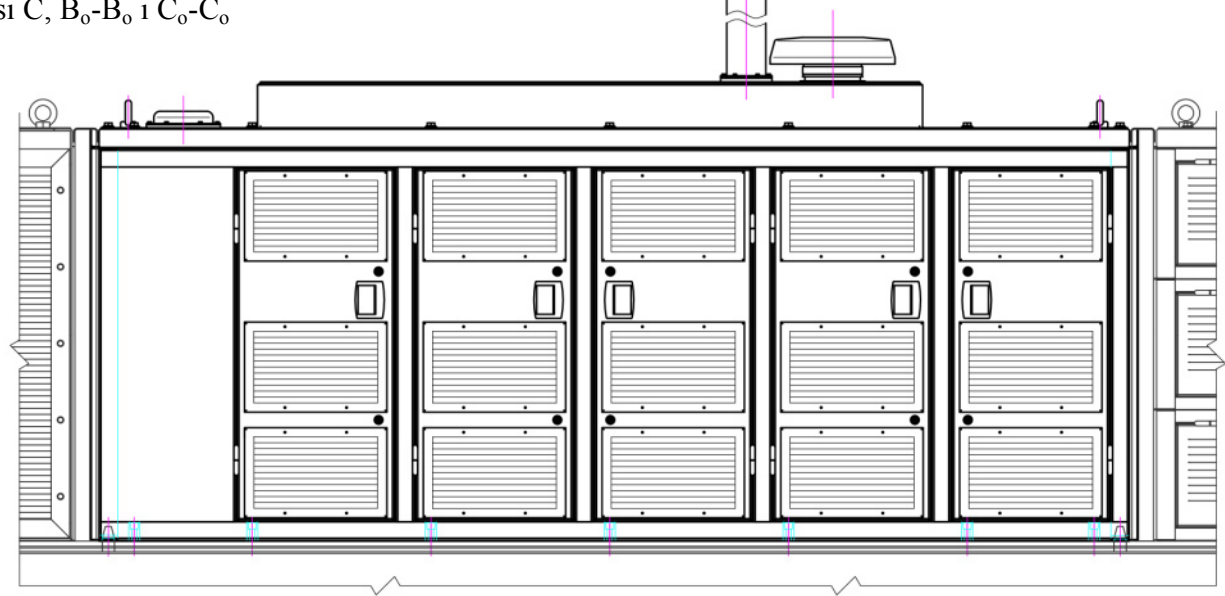

Rys.10 Zabudowa modułu zespołu prądotwórczego dla lokomotywy o układzie osi CoCo 
b) prądnicę główną o mocy $100 \mathrm{~kW}$, napięciu $700 \mathrm{~V}$, prądzie $145 \mathrm{~A}$ i obrotach $2200 \%$ min

c) prostownik trakcyjny o mocy $120 \mathrm{~kW} \mathrm{z}$ przewietrzaniem własnym

d) przetwornicę statyczną (pomocniczą) o napięciu wejściowym 400 $\div 900$ VDC, mocy wyjściowej DC - 10kW (dla 26VDC) i mocy wyjściowej AC-20kVA (dla 3x400VAC, 50Hz)

e) przekształtnik trakcyjny $\mathrm{DC} / \mathrm{DC}$ z płynną regulacja prądu o mocy $400 \mathrm{~kW}$ z przewietrzaniem własnym

f) urządzenia do kontroli i ładowania wysokowydajnych zasobników energii o napięciu wejściowym zewnętrznym 3x400VAC i wewnętrznym 700VDC, napięciu wyjściowym 700VDC, maksymalnym prądem ładowania $63 \mathrm{~A}$ i maksymalnym ciagłym prądem rozładowania 190A z przewietrzaniem własnym

g) wysokowydajny zasobnik energii zbudowany z ogniw firmy Hoppecke FNC ${ }^{\circ}$ - A190 HRC o pojemności ogniwa 190Ah, ilości ogniw 447, napięciu znamionowym modułu $537 \mathrm{~V}$, prądzie znamionowym modułu 190A, ilości energii zmagazynowanej od $102 \mathrm{kWh}$ i energii użytkowej ok. $81 \mathrm{kWh}$. W lokomotywie zabudowany będzie jeden moduł zasobnika

h) dotychczasowy silnik trakcyjny - typ LST 430 o mocy $173 \mathrm{~kW}$ zmodernizowany w zakresie izolacji i szczelności, współpracujący $\mathrm{z}$ przekładnią jednostopniową o przełożeniu 4,41. W lokomotywie będą zabudowane dwa silniki trakcyjne

2) dla lokomotywy o układzie osi $\mathrm{B}_{\mathrm{o}}-\mathrm{B}_{\mathrm{o}}$ ( $\mathrm{z}$ jednym modułem zespołu prądotwórczego i dwoma modułami wysokowydajnych zasobników energii) wytypowano:

a) silnik spalinowy typu Caterpillar C9.3 Acert o mocy $242 \mathrm{~kW}$, max obrotach $22001 / \mathrm{min}$, momencie obrotowym $1483 \mathrm{Nm}$, masie $1839 \mathrm{~kg}$ pracujący cyklicznie z pełną mocą max do $80 \%$ całkowitego czasu pracy

b) prądnicę główną o mocy $200 \mathrm{~kW}$, napięciu $700 \mathrm{~V}$, prądzie $290 \mathrm{~A}$ i obrotach $2200 \mathrm{1} / \mathrm{min}$

c) prostownik trakcyjny o mocy $240 \mathrm{~kW} \mathrm{z}$ przewietrzaniem własnym

d) przetwornicę statyczną (pomocniczą) o mocy $60 \mathrm{~kW} \mathrm{z}$ tego $10 \mathrm{~kW}$ (dla napięcia wyjściowego 26VDC) i 50kVA (dla napięcia wyjściowego $3 \mathrm{x} 400 \mathrm{VAC}, 50 \mathrm{~Hz})$

e) przekształtnik trakcyjny DC/DC o parametrach jak w [pkt 1e] (dwa przekształtniki na lokomotywę)

f) urządzenia do kontroli i ładowania wysokowydajnych zasobników energii o parametrach jak w [pkt 1f] (dwa urządzenia na lokomotywę) g) wysokowydajny zasobnik energii o parametrach jak w [pkt 1g] (dwa moduły zasobników na lokomotywę)

h) dotychczasowy silnik trakcyjny. W lokomotywie będą zabudowane cztery silniki trakcyjne

3) dla lokomotywy o układzie osi $\mathrm{B}_{0}-\mathrm{B}_{\mathrm{o}}$ (z dwoma modułami zespołu prądotwórczego i dwoma modułami wysokowydajnych zasobników energii) wytypowano:

a) silnik spalinowy o parametrach jak w [pkt 1a] (na lokomotywie zabudowane będą dwa silniki)

$\left.\begin{array}{l}\text { b) prądnica główna } \\ \text { c) prostownik trakcyjny }\end{array}\right\}$ o parametrach jak w [pkt 1b i 1c] (dwa układy na lokomotywę)

d) przetwornicę statyczną o parametrach jak w [pkt 2d]

e) przekształtnik trakcyjny DC/DC o parametrach jak w [pkt 1e] (dwa przekształtniki na lokomotywę - jeden na parę silników trakcyjnych)

f) urządzenia do kontroli i ładowania wysokowydajnych zasobników energii o parametrach jak w [pkt 1f] (dwa urządzenia na lokomotywę po jednym na każdy moduł zasobnika energii)

g) wysokowydajny zasobnik energii o parametrach jak w [pkt 1g] (dwa moduły zasobników na lokomotywę)

h) dotychczasowy silnik trakcyjny. W lokomotywie będą zabudowane cztery silniki trakcyjne

5) dla lokomotywy o układzie osi $\mathrm{C}_{0}-\mathrm{C}_{\mathrm{o}}$ (z trzema modułami zespołów prądotwórczych oraz z trzema modułami wysokowydajnych zasobników energii) wytypowano:

a) silnik spalinowy o parametrach jak w [pkt 1a] (na lokomotywie zabudowano trzy silniki spalinowe)

a) prąnica główna o parametrach

b) prostownik trakcyjny $\}\left\{\begin{array}{l}\text { jak w [pkt } 1 \mathrm{~b} \mathrm{i} \\ 1 \mathrm{c}] \text { (trzy zespoły }\end{array}\right.$ na lokomotywę)

c) przetwornicę statyczną (pomocnicza) o parametrach jak w [pkt 2d]

d) przekształtnik trakcyjny DC/DC o parametrach jak w [pkt 1e] (trzy przekształtniki na lokomotywę - po jednym na parę silników trakcyjnych)

e) urządzenia do kontroli i ładowania wysokowydajnych zasobników energii o parametrach jak w [pkt 1f] (na lokomotywie zabudowano trzy urządzenia - po jednym na każdy moduł zasobnika energii)

f) wysokowydajny zasobnik energii o parametrach jak w [pkt 1g] (na lokomotywie zabudowano trzy moduły zasobników) 
g) dotychczasowy silnik trakcyjny o parametrach jak w [pkt 4h] (na lokomotywie zabudowano sześć silników trakcyjnych).

Wytypowane zespoły i urządzenia charakteryzują się identycznymi lub porównywalnymi parametrami (i mogą być w przyszłości produkowane przez tych samych wytwórców) co zdecydowanie obniży koszty produkcji lokomotyw wyposażonych w hybrydowe układy napędowe.

Przykładowe charakterystyki pociagowe dla lokomotyw o układzie osi $\mathrm{B}_{0}-\mathrm{B}_{\mathrm{o}}$ i $\mathrm{C}_{0}-\mathrm{C}_{\mathrm{o}}$ przedstawiono na rys. 11 i 12.

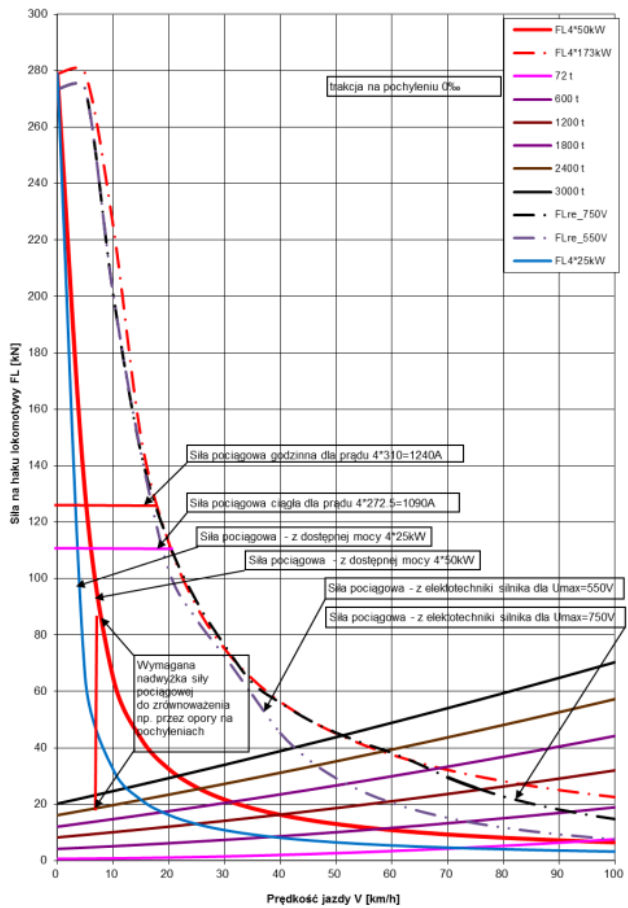

Rys.11 Charakterystyka trakcyjna dla hybrydowej lokomotywy spalinowej o układzie osi $\mathrm{B}_{\mathrm{o}}-\mathrm{B}_{\mathrm{o}}$ (cztery silniki trakcyjne)

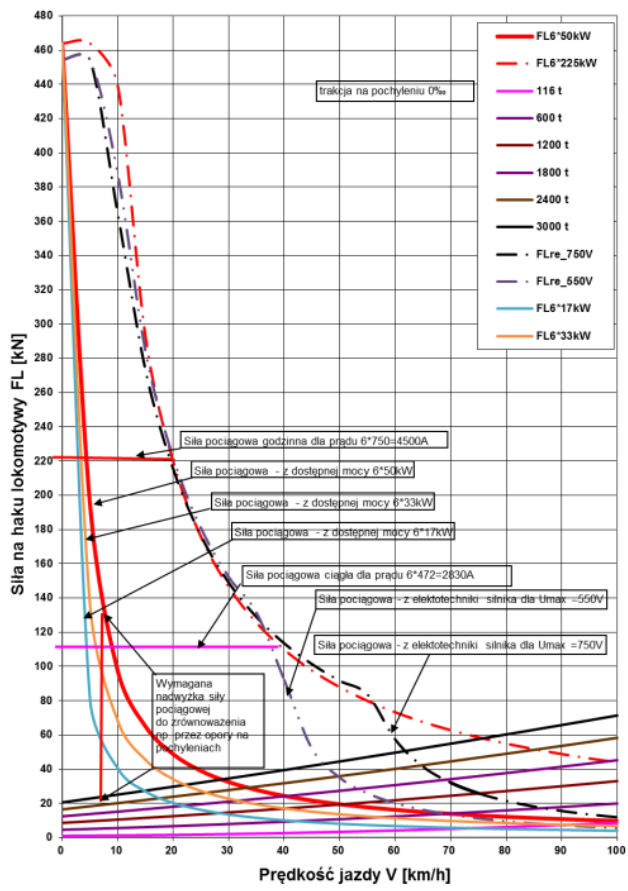

Rys.12 Charakterystyka trakcyjna dla hybrydowej lokomotywy spalinowej o układzie osi $\mathrm{C}_{0}-\mathrm{C}_{\mathrm{o}}$ (sześć silników trakcyjnych)
Przeprowadzone analizy dla przyjętych parametrów głównych zespołów wykazały, że lokomotywa o układzie osi $\mathrm{B}_{\mathrm{o}}-\mathrm{B}_{\mathrm{o}}$ może w pracy manewrowej pracować do 4 godzin na energii zgromadzonej tylko $\mathrm{w}$ wysokowydajnych zasobnikach energii nawet ze średnio ciężkimi składami pociagów.

W przypadku wykorzystania lokomotywy w pracy przetokowo-liniowej czas pracy nie przekracza 2 godzin i dla spełnienia wymagań trakcyjnych koniecznym będzie zasilanie silników trakcyjnych zarówno z wysokowydajnych zasobników energii jak i z energii dostarczanej z zabudowanego (jednego lub dwóch) zespołów prąqdotwórczych [7].

Dla lokomotywy o układzie osi $\mathrm{C}_{\mathrm{o}}-\mathrm{C}_{\mathrm{o}}$ zainstalowana pojemność wysokowydajnych zasobników energii wystarczy do pracy manewrowej do 5 godzin nawet $\mathrm{z}$ ciężkimi składami pociągów. $\mathrm{W}$ pracy liniowej energia zgromadzona w zasobnikach i dostarczona przez jeden lub trzy zespoły prądotwórcze wystarczy tylko na 1,5 godziny pracy. Najlepsze możliwości trakcyjne osiagnie się $\mathrm{w}$ pracy manewrowej dla lokomotywy o układzie osi C, mimo że pojemność wysokowydajnych zasobników energii wystarcza na około 2 godzin pracy [6].

Dla wszystkich zabudowanych zespołów prądotwórczych na poziomie $100 ; 200 ; 300 \mathrm{~kW}$ jest wystarczające, przy czym dla lokomotyw o układach osi $\mathrm{B}_{0}-\mathrm{B}_{\mathrm{o}}$ i $\mathrm{C}_{\mathrm{o}}-\mathrm{C}_{\mathrm{o}}$ wykorzystanie pełnych charakterystyk pociagowych wymagać będzie rozbudowanych układów połączeń silników trakcyjnych ze sobą w porównaniu $\mathrm{z}$ rozwiązaniami stosowanymi w lokomotywach bazowych $[6,7,8]$.

Szczegółowe wyniki wykonywanych analiz prowadzących do określenia właściwości trakcyjnych wszystkich lokomotyw, w których zabudowano hybrydowe układy napędowe zostały przedstawione $\mathrm{w}$ pracach $[6,7,8,13]$.

\section{PODSUMOWANIE}

Rozwój lokomotyw spalinowych wyposażonych w hybrydowe układy napędowe przeznaczanych zasadniczo do prowadzenia prac manewrowych i przetokowych jest widoczny w wielu krajach europejskich takich, jak Francja, Niemcy, Szwajcaria, Rosja, Szwecja, a także w USA, Kanadzie i Japonii.

W Polsce wstępne prace rozpoczęte na przełomie 2010/2011 r. bazowały na doświadczeniach innych krajów i skoncentrowały się na wykorzystaniu znanych i eksploatowanych spalinowych lokomotyw manewrowych jako bazowych do zabudowy układów napędu hybrydowego.

W ciagu około trzech lat prowadzenia prac rozwojowych przez specjalistów i naukowców Instytutu Pojazdów Szynowych „Tabor” i Instytutu Silników 
Spalinowych i Transportu Politechniki Poznańskiej wykonano szereg zadań zakończonych przygotowaniem dokumentacji konstrukcyjnej układów napędu hybrydowego dla wybranych zmodernizowanych lokomotyw spalinowych o układach osi $\mathrm{C}, \mathrm{B}_{\mathrm{o}^{-}}-\mathrm{B}_{\mathrm{o}} \mathrm{i}_{\mathrm{C}} \mathrm{o}^{-}$ $\mathrm{C}_{\mathrm{o}}$, dla których przygotowano również koncepcje oraz wytyczne i wymagania dla prowadzenia dalszych prac projektowych.

Naszym zdaniem efektów uzyskanych podczas realizacji projektu rozwojowego nie można zaprzepaścić i należy dążyć do uruchomienia dalszych prac, w których należałoby:

- przygotować model (modele) użytkowy układu napędu hybrydowego oraz układów jego sterowania $\mathrm{i}$ diagnostyki wraz $\mathrm{z}$ jego wszechstronnym przebadaniem i przetestowaniem

- opracować pełną dokumentację konstrukcyjną lokomotywy dla jednego lub kilku wariantów napędów

- wykonać prototyp (prototypy) lokomotyw spalinowych $\mathrm{z}$ najlepszym rozwiązaniem hybrydowego układu napędowego

- przeprowadzić wszechstronne próby i badania stacjonarne i ruchowe wykonanej lokomotywy

- przeprowadzić próby eksploatacyjne podczas wykorzystania lokomotywy na bocznicach oraz na szlakach liniowych

- dopuścić lokomotywę do ruchu manewrowo-przetokowego.

Prace te byłoby można realizować $\mathrm{w}$ ramach uruchomionego projektu celowego lub $\mathrm{w}$ ramach konsorcjum złożonego z zainteresowanego użytkownika, wykonawcy i jednostki naukowo-badawczej.

\section{Bibliografia}

[1] Marciniak Z.: Hybrydowe uklady napędowe lokomotyw spalinowych, Logistyka, $2010 \mathrm{nr} 4$.

[2] Marciniak Z.: Napędy hybrydowe pojazdów trakcji elektrycznej i spalinowej, Pojazdy Szynowe, 2011 nr 4.

[3] Marciniak Z., Jakuszko W.: Koncepcja polskiej lokomotywy spalinowej z hybrydowym uktadem napędowym, Pojazdy Szynowe, $2012 \mathrm{nr} 4$.

[4] Marciniak Z., Mielniczuk J.: Polska koncepcja lokomotywy spalinowej $z$ hybrydowym uktadem napędowym, Prace naukowe Politechniki Warszawskiej, Seria Transport. Z. 98 - Środki i infrastruktura transportu, Warszawa 2013.

[5] Marciniak Z., Mielniczuk J.: Lokomotywy spalinowe jednokabinowe do prac manewrowych $i$ przetokowych $z$ hybrydowym uktadem napędowym (koncepcja i założenia), Problemy Kolejnictwa, 2014 (zgłoszony do druku).

[6] Praca zbiorowa. Koncepcja spalinowej lokomotywy manewrowej $i$ przetokowej o uktadzie osi $C$ $z$ zabudowanym hybrydowym ukladem napędowym. Opracowanie OR-10373, IPS “Tabor”, Poznań, 12.2013.

[7] Praca zbiorowa. Koncepcja spalinowej lokomotywy manewrowej $i$ przetokowej o uktadzie osi $B_{o}-B_{o}$ $z$ zabudowanym hybrydowym uktadem napędowym. Opracowanie OR-10374, IPS “Tabor”, Poznań, 12.2013.

[8] Praca zbiorowa. Koncepcja spalinowej lokomotywy manewrowej $i$ przetokowej o uktadzie osi $C_{o}-C_{o}$ $z$ zabudowanym hybrydowym uktadem napędowym. Opracowanie OR-10375, IPS “Tabor”, Poznań, 12.2013.

[9] Praca zbiorowa. Dokumentacja hybrydowego uktadu napędowego lokomotywy spalinowej o uktadzie osi C (w zastosowaniu do zmodernizowanej lokomotywy spalinowej typu 401Da). Opracowanie PR 10 006210-401, IPS "Tabor", Poznań, 11.2013.

[10] Praca zbiorowa. Dokumentacja hybrydowego uktadu napędowego lokomotywy spalinowej o uktadzie osi $B_{o}-B_{o}$ (w zastosowaniu do zmodernizowanej lokomotywy spalinowej typu 6D). Opracowanie PR 10 006210-42, IPS “Tabor", Poznań, 11.2013.

[11] Praca zbiorowa. Dokumentacja hybrydowego uktadu napędowego lokomotywy spalinowej o układzie osi $C_{o}-C_{o}$ (w zastosowaniu do zmodernizowanej lokomotywy spalinowej typu TEM2). Opracowanie PR 10 006210-48, IPS “Tabor”, Poznań, 11.2013.

[12] Praca zbiorowa. Wytyczne $i$ wymagania $w$ zakresie wykonania dokumentacji konstrukcyjnej lokomotyw spalinowych z hybrydowym ukladem napędowym. Opracowanie OR 10482, IPS “Tabor”, Poznań, 03.2014.

[13] Praca zbiorowa. Podstawowe parametry głównych zespołów wchodzacych $w$ sktad hybrydowego uktadu napędowego wybranych spalinowych lokomotyw manewrowych. Opracowanie OR 10497, IPS "Tabor", Poznań, 03.2014. 